Rok XVI (2021) | 1 (31) | S. 271-281

https://doi.org/10.12797/LV.16.2021.31.22

Maciej Rak • (1)

Uniwersytet Jagielloński, Kraków

maciej.rak@uj.edu.pl

\title{
JAKI JEST WŁAŚCIWIE ZAKRES DIALEKTOLOGII HISTORYCZNEJ? (UWAGI Z PERSPEKTYWY DIALEKTOLOGA)
}

Słowa klucze: dialektologia historyczna, gwary polskie, socjolingwistyka

Keywords: historical dialectology, Polish dialects, sociolinguistics

\section{Dialektologia historyczna - ujęcie Witolda Taszyckiego i Kazimierza Nitscha}

Czym jest dialektologia historyczna, możemy się dowiedzieć m.in. z artykułów Kazimierza Nitscha (1948) i Witolda Taszyckiego ${ }^{1}$ (1956), które nieprzypadkowo są tak samo zatytułowane - Co to jest dialektologia historyczna? Obydwu autorom chodziło o sprecyzowanie przedmiotu i metody tego typu badań, ale W. Taszycki, powtarzając bez zmian tytuł artykułu K. Nitscha, bezpośrednio ujawnił polemiczną intencję swojej wypowiedzi. Dla Nitscha dialektologia historyczna była przede wszystkim podstawą dla dialektologii opisowej (tak jak gramatyka historyczna wyjaśnia procesy obserwowane we współczesnej polszczyźnie). Z kolei Taszycki, jako historyk języka, wiedzę o staropolskich dialektach czerpaną ze źródeł filologicznych wykorzystywał w celu odpowiedzi na pytanie o pochodzenie polskiego języka literackiego (Taszycki 1930, 1949, 1951). Oczywiście problem ten był podejmowany

1 Dorobek W. Taszyckiego w zakresie dialektologii historycznej został przybliżony przez Bogusława Dunaja (1981), z kolei większość prac uczonego dotyczących tego tematu przedrukowano w tomie Dialektologia historyczna i problem pochodzenia polskiego języka literackiego (Taszycki 1961). Warto w tym miejscu przywołać także artykuły Józefa Kościa (2000, 2003), w których znajdziemy szczegółowe omówienie dyskusji dotyczącej metod i zakresu dialektologii historycznej. 
także przez Nitscha (1913), który dowodził, że polszczyzna literacka ukształtowała się w Wielkopolsce. Ujawniające się w ten sposób dwa różne cele (dialektologiczny i historycznojęzykowy) odpowiadają za rozbieżności w decydowaniu o tym, czy pierwszeństwo mają współczesne dane dialektologiczne czy też informacje uzyskane z zabytków językowych.

Największy polski dialektolog zaproponował za Władysławem Kuraszkiewiczem (1936) wyszczególnienie dwóch rodzajów dialektologii historycznej - filologicznej, inaczej staropolskiej, czyli opierającej się na badaniu zabytków językowych, oraz lingwistycznej, odwołującej się do danych ze współczesnych mu gwar (Nitsch 1948). W artykule Co wiemy naprawdę o dialektach ludowych XVI wieku? (1953) Nitsch pokazał praktyczne zastosowanie takiego ujęcia na przykładach: ekspansywnych cech mazowieckich (fonetyki międzywyrazowej nieudźwięczniającej; twardego $m$, np. rękamy; twardego li, np. robily; wymowy typu śfat, śféca oraz elementów leksykalnych, np. przyboś 'w bucie na bosą nogę'), ekspansywnych cech wielkopolskich (wielkopolskiego $e$, które wyparło małopolskie $a ; n$ tylnojęzykowego w formach $p a$ nienka, koronka) i mazurzenia. Rzecz jasna, najważniejsze i rozstrzygające były tu odwołania do gwar, które badał w terenie.

Z kolei W. Taszycki w przywołanym wyżej artykule ten typ danych uznał za mniej istotny, por.:

Wiodą ku temu [określeniu historycznego rozwoju polskich dialektów - M.R.] przede wszystkim stosunki dialektyczne w zabytkach języka naszego w najszerszym tego słowa znaczeniu notowane, następnie różnej wartości, zawsze jednak cenne wzmianki o dialektyzmach poczynione przez gramatyków i słownikarzy, z kolei obserwacje z dziedziny chronologii względnej pozwalające niekiedy przynajmniej z grubsza określić wiek badanego zjawiska dialektycznego, w końcu rozpatrzenie wybranego zjawiska lub grupy zjawisk na tle całości współczesnych dialektów oraz ich geograficznego rozmieszczenia, a następnie wydobycie stąd wskazówek mogących rzucić światło na przeszłość analizowanego zagadnienia (Taszycki 1956: 279-280),

i przytoczył kontrargumenty, które miały podważyć wnioskowanie Nitscha.

Polemika obydwu badaczy, a także znaczna liczba prac z dialektologii historycznej (nie będę ich tu wymieniał, gdyż wykaz taki znajdziemy np. w książce Mirosławy Mycawki (2012: 30)) zainspirowały Karola Dejnę do - jak zapowiedział w Dialektach polskich (1973: 19) - ujmowania procesów językowych nie tylko na podstawie danych dialektograficznych, ale też w aspekcie historycznojęzykowym, co miało pozwolić na ustalenie ich przypuszczalnej genezy. Jednak - jak się okazało - w tym opracowaniu Dejna szczegółowo zrealizował tylko pierwszą część założonego celu, a drugą - z racji tego, że był dialektologiem, a nie historykiem języka - ujął w sposób niezadowalający.

W dalszym ciągu nie dysponujemy więc nawet zarysem kompleksowej dialektologii historycznej, choć z takim pomysłem przed 65 laty wystąpił W. Taszycki 
(1956: 279) i rozwinął go we Wstępie do Zarysu historycznej dialektologii polskiej (1973). Później ten postulat ponawiali, mając na uwadze historię języka, m.in. Bogusław Dunaj (1981: 397, 1987: 93) i Mirosława Mycawka (2012: 34). Rozwój badań w zakresie polskiej dialektologii historycznej omówił z kolei Jerzy Reichan w nieopublikowanym dotychczas artykule ${ }^{3}$ (por. Bibliografia JR: 15).

\section{Punkt odniesienia w dialektologii}

To, co w zakresie stanu gwar było współczesne Nitschowi i z czym konfrontował on fakty z historii dialektów, obecnie należy już do historii, i to wcale nie takiej bliskiej. Zasięg dialektów i regularność cech gwarowych opisane przez niego (Nitsch 1910a, b, 1911, 1915/1957) dotyczyły początku XX w., a jeśli weźmiemy pod uwagę to, że prowadził on badania retrospektywne wśród najstarszych mieszkańców wsi (Rzetelska-Feleszko 2002: 107-108), możemy założyć, że część informacji dostarczyły mu osoby urodzone w 1. połowie XIX w., czyli, licząc od dziś, około siedmiu pokoleń wstecz (przy założeniu, że następstwo pokoleń dokonuje się co 25 lat). Punktem odniesienia dla Taszyckiego, który nie prowadził badań dialektologicznych $\mathrm{w}$ terenie, też były prace Nitscha. Właściwie wszystkie syntezy polskiej dialektologii (Urbańczyk 1953; Dejna 1973; Karaś Kompendium) bazują w mniejszym lub większym stopniu na ustaleniach tego językoznawcy.

Dziś - w porównaniu z sytuacją językową opisywaną przez Nitscha - na polskiej wsi zaszły bardzo poważne, wręcz rewolucyjne zmiany. Wielkie migracje ludności po 1945 r. (według Jacka Warchali (2003: 153) w migracji wewnętrznej na pobyt stały w latach 1949-2000 wzięło udział ok. 49,9 mln Polaków), możliwość awansu, postęp cywilizacyjny, nowe maszyny i sposoby uprawy, oddziaływanie prasy, radia, telewizji i Internetu, osiedlanie się na wsi ludzi z miast, okresowe wyjazdy do pracy ze wsi do miast i za granicę - wszystko to sprawiło, że już od kilkudziesięciu lat obserwujemy dezintegrację większości gwar (więcej i dokładniej o tym, wraz z powołaniami na bogatą literaturę, zob. Karaś Kompendium - Jaki jest dziś język mieszkańców wsi?). 22 lata temu tak o kondycji gwar pisał J. Reichan:

O ile kilkadziesiąt lat temu gwary utrzymywały się jeszcze całkiem dobrze, tak że można było łatwo znaleźć na wsi młodych informatorów dobrze mówiących gwarą, o tyle obecnie nie jest to prawie możliwe. $W$ ostatnich latach praca dialektologa zaczyna przypominać badania archeologa: jest to uciążliwe doszukiwanie się u najstarszych osób we wsi resztek gwarowego systemu (Reichan 1999: 263).

2 Taki tytuł nosił wykład W. Taszyckiego głoszony na Uniwersytecie Jagiellońskim (Karpluk 1980: 141).

3 Niniejszym dziękuję prof. J. Reichanowi za udostępnienie komputeropisu tej pracy. 
Opisana tu sytuacja oczywiście przybiera na sile, o czym przekonały mnie różne badania terenowe, szczegółowe obserwacje prowadzone w Dębnie (mojej rodzinnej wsi) w Górach Świętokrzyskich, prace innych dialektologów (np. Kurek 1997; Kąś, Kurek 2001; Pelcowa 2002, 2012, 2019; Sierociuk 2005, 2007) oraz opinie studentów z różnych części Polski. Podam kilka aktualnych przykładów, można je z pewnością mnożyć i odnosić do różnych części kraju.

Często studenci pochodzący ze wsi zlokalizowanych w tych regionach, które są uznawane za mazurzące, twierdzą, że tam już się nie mazurzy, bywa nawet, że zjawisko to jest rzadkością w wypowiedziach najstarszych osób (co potwierdzają nagrania $^{4}$ przygotowane jako prace zaliczeniowe na kurs dialektologii i socjolingwistyki i co jest wynikiem tego, że mazurzenie należy do najbardziej rozpoznawalnych cech gwarowych). Pod Krakowem (na południe i zachód od tego miasta) coraz trudniej spotkać przykłady przejścia wygłosowego $-x \mathrm{w}-k$. W Górach Świętokrzyskich nigdy nie zanotowałem znamiennej dla tej części Małopolski przestawki -źr- > -rź-, -śr-> -rś-, a jedynym jej świadectwem jest zleksykalizowane, ale przy tym recesywne spor-zić 'spojrzeć. Także z literatury naukowej dowiedziałem się, że występowały tu końcówka -e w D. lp. rz. ż. miękkotematowych, np. do stajnie, do kuchnie, i ślady przejścia $-x>-k$. Jak wiadomo, ze względu na wyjątkowy prestiż w lepszym stanie zachowały się do dziś gwary Śląska ${ }^{5}$ (np. Tambor 2006) i Podtatrza (szczególnie na Podhalu daje się zauważyć pewnego rodzaju petryfikację gwary poprzez jej użycie $\mathrm{w}$ literaturze regionalnej ${ }^{6}$, podobne uwagi w odniesieniu do śląszczyzny poczyniła Jolanta Tambor (2015)), ale różnice pokoleniowe i tu są już bardzo wyraźne, co w odniesieniu do materiału orawskiego i podhalańskiego oddają słowniki Józefa Kąsia (KąśSGO, KąśILG).

Środowisko dialektologiczne jest oczywiście świadome zasygnalizowanych wyżej zmian (por. Kurek 1995, 2003) ${ }^{7}$, dlatego zamiast o gwarze często mówi się o języku

4 Mam świadomość, że mogła tu zaważyć pewnego rodzaju oficjalność, która prowadzi do przełączania kodu z gwarowego na niegwarowy (więcej o tym w: Kurek 1987; Kąś 1994), jednak część nagrań dotyczyła nie pojedynczych informatorów, lecz grupy, w której łatwiej o spontaniczną wypowiedź, a mimo to nie zostało poświadczone mazurzenie.

5 Rzecz jasna, należy tu oddzielić sytuację językową miast śląskich od sytuacji, jaka panuje na wsiach tego regionu. W tych pierwszych gwara znacznie szybciej i mocniej interferuje z polszczyzną ogólną.

6 Dokładniejsze przyjrzenie się tego typu tekstom przekonuje, że - w porównaniu z potocznymi użyciami gwary - są one nasycone archaizmami, terminologią pasterską, która jest typowa dla gwar karpackich, i dawniejszymi zapożyczeniami (por. np. Rak 2018).

7 Dotyczyły tego m.in. krakowskie konferencje: 1) „Dialektologia - teoria, metodologia, gramatyka, słownictwo” (26-28 XI 1993 r., Mogilany; organizatorzy - IJP PAN i IFP UJ); 2) „Problemy badawcze współczesnej dialektologii" (18-19 XI 1999 r., Mogilany; organizatorzy - IJP PAN i IFP UJ); 3) "Języki słowiańskie w ujęciu socjolingwistycznym” (10-11 VI 2011 r., Kraków; organizator - WP UJ); 4) „Gwara i tekst” (27-28 IX 2013 r., Kraków; organizator - WP UJ).

Materiały z pierwszej sesji wyszły jako Studia Dialektologiczne I pod red. B. Dunaja i J. Reichana (1996), z kolei referaty wygłoszone w 1999 r. opublikowano w Studiach Dialektologicznych II pod 
wsi (Kąś, Kurek 2001) lub języku mieszkańców wsi (Sierociuk 2007), a także na nowo definiuje się termin gwara ludowa (to przymiotnikowe dookreślenie jest konieczne w związku z tym, że oddzielnie bada się gwary miejskie i środowiskowe), jak zrobiła to Halina Karaś, eksponując niejednolitość kodu używanego na wsi, por.:

Gwara ludowa to mówiony wariant terytorialny (lokalny) języka narodowego, używany tylko na pewnym stosunkowo niewielkim terenie; jedna z odmian języka używana przez mieszkańców wsi, ukształtowana kiedyś w obrębie warstwy chłopskiej, podrzędna w stosunku do dialektu. Różni się ona wymową, cechami gramatycznymi (morfologicznymi, składniowymi) i słownictwem od języka ogólnego. W niedalekiej jeszcze przeszłości była to odmiana terytorialno-socjalna, czyli taka, której używano na pewnym obszarze i tylko w określonej warstwie społecznej - chłopskiej ${ }^{8}$.

Jeśli zaś idzie o przyszłość polskich gwar ludowych, to badacze są raczej zgodni co do tego, że interferencja z polszczyzną ogólną w wielu wypadkach doprowadziła już, a w innych najprawdopodobniej doprowadzi do powstania kodu o zasięgu ograniczonym do relacji nieoficjalnych, sąsiedzkich, rodzinnych, a może też lokalnych, kodu, który jest lub będzie „trzecią jakością”, różniącą się i od polszczyzny ogólnej, i od gwary (więcej o tym pisał Bogusław Nowowiejski (2001), referując stanowiska innych badaczy). Przypominam, że te uwagi nie w pełni odnoszą się do śląszczyzny i gwar Podtatrza.

Z drugiej jednak strony, zwłaszcza w ostatnim piętnastoleciu (niebagatelne znaczenie miały tu wstąpienie Polski do Unii Europejskiej oraz ratyfikacja przez nasz kraj w 2011 r. Konwencji UNESCO w sprawie ochrony niematerialnego dziedzictwa kulturowego z 2003 r.) pojawiają się inicjatywy mające na celu dokumentowanie kultury ludowej i gwar. Zaważyły na tym: zwiększenie świadomości językowej Polaków, większa liczba inteligentów pochodzenia wiejskiego, wzrost prestiżu małych ojczyzn i dostępność programów finansowych. W ten właśnie sposób w ramach projektu Narodowego Centrum Kultury Ojczysty - dodaj do ulubionych Sekcja Dialektologii i Socjolingwistyki Koła Naukowego Językoznawców Studentów UJ im. Mieczysława

red. Joanny Okoniowej i B. Dunaja (2002). Część artykułów umieszczonych w kolejnych tomach tej serii (a jest ich aktualnie 5) także dotyczy zmieniającej się sytuacji polskich gwar. Materiały z konferencji „Języki słowiańskie w ujęciu socjolingwistycznym” opublikowano pod takim samym tytułem pod red. Haliny Kurek (2012), a referaty wygłoszone w 2013 r. wydano w monografii zbiorowej Badania dialektologiczne. Stan, perspektywy, metodologia pod red. Macieja Raka i Kazimierza Sikory (2014). Zagadnienie to jest wreszcie omawiane w roczniku (wcześniej serii, a od 2015 r. czasopiśmie, nieformalnym organie Komisji Dialektologicznej przy Międzynarodowym Komitecie Slawistów) „Gwary Dziś”, którego redaktorem jest Jerzy Sierociuk (chodzi mi tu zwłaszcza o tom 3. pt. Wewnętrzne zróżnicowanie języka wsi (Sierociuk 2006)). Wiele prac o współczesnej sytuacji gwar jest rozsianych w różnych czasopismach i tomach zbiorowych. Dyskutowano o tym także na licznych konferencjach i zebraniach organizowanych przez inne ośrodki naukowe niż krakowski.

8 http://www.dialektologia.uw.edu.pl/index.php?l1=leksykon\&lid=592 (dostęp: 1 X 2020). 
Karasia przeprowadziła w latach 2017-2018 badania w gminie Wiśniowa, które zaowocowały książką Słownictwo i kultura ludowa gminy Wiśniowa (Słownictwo) ${ }^{9}$.

Wszystko to, co zostało przybliżone w tej części artykułu, przekonuje do konstatacji, że dziś - z perspektywy dialektologicznej - syntezy K. Nitscha należą do dialektologii historycznej (tym samym zmienia się jej zakres), bowiem dokumentują stan gwar z przełomu XIX i XX w., które współcześnie w zdecydowanej większości uległy dezintegracji. Nie ma jednak wątpliwości, że dla historyków języka w dalszym ciągu prace największego polskiego dialektologa będą punktem odniesienia obserwowanych przez nich zjawisk z dialektów staropolskich, bowiem dotyczą systemu gwarowego nierozchwianego pod wpływem polszczyzny ogólnej. Już na tym przykładzie widać różnice $\mathrm{w}$ traktowaniu materiału dialektalnego przez dialektologów i historyków języka - pierwsi zwracają uwagę na dynamikę zmian ostatnich dziesięcioleci, odnosząc ją do stanu opisywanego przez Nitscha, dla drugich ważniejsze jest to, co działo się w zakresie relacji dialekty staropolskie - kształtująca się polszczyzna ogólna (ponaddialektalna).

\section{Do czego się przydają prace dialektologiczne dokumentujące gwary 1. połowy XX w.?}

Zmiany sytuacji językowej na wsi wymuszają zmiany w metodach badań (więcej patrz np. Kurek 1990; Kąś 2001; Pelcowa 2001; Sierociuk 2007, 2016) i zredefiniowanie nie tylko tego, co jest przedmiotem dialektologii (por. umieszczoną wyżej definicję gwary ludowej), ale też jej celów. Dla Nitscha podstawowym celem było „zajmowanie się przeważnie tylko dzisiejszą geografią języka” (1915/1957: 7), tak też dialektologię ujęto w EWJP (s. 67) i EJO (s. 110).

Dla współczesnych dialektologów jednym z celów (obok ściśle naukowych, czyli opisu tego, jak dziś mówi się na wsi, łącznie z opisem innowacji i przykładami nowego folkloru) jest ochrona ginących gwar (Karaś 2015), w obrębie której mieści się też ich rewitalizacja ${ }^{10}$, jeśli zanikły bądź są używane sporadycznie, szczątkowo. Rewitalizacja zakłada przywrócenie gwary do użytku, ale, rzecz jasna, nie do użytku stałego (tę potrzebę zapewnia na wsi „trzecia jakość”), lecz okazjonalnego - np. do działalności zespołów regionalnych i na konkursy ${ }^{11}$ (znamienne jest to, że na takich

9 Wcześniej na pograniczu góralsko-lasko-krakowskim badania prowadzili: Lucjan Malinowski (1880), Stanisław Dobrzycki (1907), Edward Klich (1910), Antoni Małecki (1928: 17; AJPP - tu punkt 18., czyli wieś Lipnik) i Jerzy Reichan (1980).

10 Zdaję sobie sprawę, że zasadność rewitalizacji może wywoływać dyskusję. Według mnie, jeśli jednak impuls wychodzi od społeczności wiejskiej, to dialektolodzy powinni służyć radą i pomocą podczas prób przywracania gwary jako systemu językowego (o przywracaniu dawnych wierzeń, przesądów, obyczajów i systemu wartości nie ma przecież mowy).

11 Składa się to na pewnego rodzaju sfolkloryzowanie kultury wsi. Osobną sprawą jest zjawisko tzw. gwary na sprzedaż, czyli używania gwary lub języka stylizowanego na gwarę w sytuacjach ko- 
konkursach ocenia się zwykle dobór repertuaru, strój oraz właśnie poprawność $\mathrm{w}$ zakresie gwary $\left.{ }^{12}\right)$. Aby coś rewitalizować, jest potrzebna wiedza, jak to pierwotnie wyglądało, i m.in. do tego właśnie są dziś przydatne prace K. Nitscha (zwłaszcza Wybór polskich tekstów gwarowych (Nitsch 1968)) i innych dialektologów działających w 1. połowie XX w. ${ }^{13}$ Bardzo ważne są też inicjatywy takie, jak Dialektologiczna fonoteka Wydziału Polonistyki UJ (http://www.fonoteka.polonistyka.uj.edu.pl/), w których znalazły się nagrania gwarowe z różnych części Polski, w tym od informatorów urodzonych pod koniec XIX w. Nie muszę przekonywać, że zapis dźwiękowy w badaniach dialektologicznych zawsze będzie miał przewagę nad zapisem literowym.

Co jednak zrobić, gdy gwara danej wsi nie zachowała się nawet u najstarszych mieszkańców, a dotycząca jej dokumentacja jest niewystarczająca albo jej po prostu nie ma? W takich wypadkach pozostają: 1) rekonstruowanie gwary (dokładniej o sposobach ustalania cech gwarowych na podstawie różnych przesłanek czytaj w artykule Mariana Kucały (2002)) i/lub 2) kwerenda archiwalna (w muzeach etnograficznych, instytucjach nauki i szkolnictwa) w poszukiwaniu niepublikowanych zapisów gwarowych, która często przynosi bardzo dobre efekty (o pożytku z tego typu badań np. w: Rak 2011). Dla przykładu: grupa z Poręby Radlnej, która 20 IX 2020 r. otrzymała pierwszą nagrodę podczas Dożynek Prezydenckich, wystąpiła w Warszawie wspólnie z zespołem ludowym „Otfinowianie”. Członkowie zespołu zaprezentowali obrzęd dożynkowy oparty na autentycznych tekstach z 1878 r., znalezionych w Muzeum Etnograficznym im. Seweryna Udzieli w Krakowie.

\section{Uwagi końcowe}

Punktem odniesienia dla prac W. Taszyckiego i innych, działających później historyków języka były i są nadal dokonania K. Nitscha, jednak obecnie dla dialektologów przedstawiają już one właściwie wartość historyczną i/lub normatywną (w wypadku działań rewitalizacyjnych) jako świadectwo tego, jak się mówiło na wsi mniej więcej przed stu laty. O ile mi wiadomo, w publikacjach dotyczących dialektologii histo-

mercyjnych. Zwykle dokonuje się to bez udziału głosu doradczego dialektologów, w wyniku czego czasem otrzymujemy wręcz karykaturalne realizacje.

12 Częstym dylematem jury Przeglądu Młodych Recytatorów i Gawędziarzy im. Andrzeja Skupnia Florka organizowanego w Białym Dunajcu jest m.in. to, jak oceniać poprawność gwarową uczestników np. z Gliczarowa Górnego i Nowego Targu. Obydwie miejscowości znajdują się na Podhalu, jednak stopień zachowania gwary jest w nich diametralnie różny, z korzyścią dla Gliczarowa Górnego. Dodatkową kwestią jest to, że uczestnicy przeglądu przygotowują się do niego pod okiem nauczycieli, najczęściej języka polskiego. Jeśli nauczyciel nie zna gwary, a przecież nie jest to wymóg konieczny, aby podjąć pracę w szkolnictwie, wówczas nie jest w stanie skorygować błędnych realizacji swojego podopiecznego.

13 Czerpią z nich również np. socjologowie wsi i etymologowie, powszechnie bowiem wiadomo, że gwary przechowują dawne słownictwo. 
rycznej w milczący sposób przyjmuje się, że stan gwar opisany przez Nitscha trwa nadal. Dynamiczne zmiany na polskiej wsi wymagają zrewidowania tego poglądu i tym samym zakresu dialektologii historycznej, do której ze współczesnej perspektywy należą już prace opisujące gwary 1. połowy XX w. Inne potrzeby, takie jak zdefiniowanie gwary na nowo i określenie celów dialektologii, zostały już zrealizowane.

\section{Literatura}

AJPP: M. Małecki, K. Nitsch, Atlas językowy polskiego Podkarpacia, cz. I: Mapy, cz. II: Wstęp, objaśnienia, wykazy wyrazów, Kraków 1934.

Bibliografia JR: Bibliografia prac Jerzego Reichana za lata 2010-2018, [w:] B. Grabka, R. Kucharzyk, A. Tyrpa (red.), Studia Dialektologiczne V, Kraków 2019, s. 13-15.

Dejna K., 1973, Dialekty polskie, Wrocław - Warszawa - Kraków - Gdańsk.

DobRZYCKI S., 1907, Samogłoski nosowe w gwarze kilkunastu wsi góralskich w pow. myślenickim i limanowskim, „Materiały i Prace Komisji Językowej Akademii Umiejętności” III, s. $59-67$.

DunAJ B., 1981, Historia języka polskiego i dialektologia historyczna $w$ badaniach Witolda Taszyckiego, „Poradnik Językowy” nr 8-10, s. 393-40o.

Dunaj B., 1987, Dialektologia historyczna - zakres i metody badań, [w:] M. Basaj, W. Boryś, H. Popowska-Taborska (red.), Slawistyczne studia językoznawcze, Wrocław - Warszawa - Kraków - Gdańsk - Łódź, s. 87-93.

Dunaj B., Reichan J. (red.), 1996, Studia Dialektologiczne I, Kraków.

EJO: K. Polański (red.), Encyklopedia językoznawstwa ogólnego, Wrocław - Warszawa - Kraków 1993.

EWJP: S. Urbańczyk (red.), Encyklopedia wiedzy o języku polskim, Wrocław - Warszawa Kraków - Gdańsk 1978.

KARAś H., 2015, Zadania dialektologii w zakresie ginących gwar, „Gwary Dziś” VII, s. 83-95.

Karaś Kompendium: H. Karaś (red.), Dialekty i gwary polskie. Kompendium internetowe, [on-line:] http://www.dialektologia.uw.edu.pl/index.php?l1=start.

Karpluk M., 1980, Witold Taszycki (2o VI 1898-8 VIII 1979), „Biuletyn Polonistyczny” 23, nr 1-2 (75-76), s. 141-144.

Kąś J., 1994, Interferencja leksykalna słownictwa gwarowego i ogólnopolskiego. Na przykładzie gwar orawskich, Kraków.

KĄś J., 2001, Metodologia badań leksyki gwarowej w kontekście współczesnych przemian kulturowych i społecznych, [w:] J. Sierociuk (red.), Gwary dziś, t. 1: Metodologia badań, Poznań, s. 191-200.

Kąś J., Kurek H., 2001, Język wsi, [w:] S. Gajda (red.), Język polski, „Najnowsze Dzieje Języków Słowiańskich", Opole, s. 440-459.

KąśILG: J. Kąś, Ilustrowany leksykon gwary i kultury podhalańskiej, t. I: A-B, Bukowina Tatrzańska - Nowy Sącz - Nowy Targ 2015, t. II: C-Do, Bukowina Tatrzańska - Nowy Sącz - Nowy Targ 2015, t. III: Dó-Gr, Bukowina Tatrzańska - Nowy Targ 2016, t. IV: Gu-Kol, Kraków 2017, t. V: Koł-Mad, Nowy Sącz 2017, t. VI: Maf-Nie, Nowy Sącz 2018, t. VII: Nif-Pap, Nowy Sącz 2018, t. VIII: Par-Pou, Nowy Sącz 2018, t. IX: Pow-Sce, Nowy Sącz 2019, t. X: Sch-Śró, Nowy Sącz 2019, t. XI: Śry-Wych, Nowy Sącz 2019, t. XII: Wyci-Ż, Nowy Sącz 2019. 
KąśSGO: J. Kąś, Słownik gwary orawskiej, Kraków 2003; wyd. 2., t. 1-2, Kraków 2011.

KLICH E., 1910, Materiały etnograficzne z południowo-zachodniej części pow. limanowskiego. Teksty gwarowe, "Materiały Antropologiczno-Archeologiczne i Etnograficzne” 11, s. $3-47$.

Kość J., 2000, Aspekty historyczne dialektologii opisowej a dialektologia historyczna, [w:] W. Książek-Bryłowa, H. Duda (red.), Język polski. Współczesność, historia 1, Lublin, s. $173-182$.

Kość J., 2003, Kazimierza Nitscha $i$ Witolda Taszyckiego koncepcja rekonstrukcji historycznodialektalnej, [w:] W. Książek-Bryłowa, H. Duda (red.), Język polski. Współczesność, historia 4, Lublin, s. 269-284.

KucaŁa M., 2002, Rekonstruowanie gwary, [w:] J. Okoniowa, B. Dunaj (red.), Studia Dialektologiczne II, Kraków, s. 53-59.

KuraszkiewiCz W., 1936, Współczesne zagadnienia polskiej dialektologii historycznej (Wstępny wykład na KUL 9 października 1936 roku), „Prąd” XXIII, s. 187-197.

Kurek H., 1987, Przełązanie kodu językowego, czyli socjolingwistyczne aspekty wzajemnego oddziaływania języka literackiego i dialektów, „Język Polski” LXVII, s. 63-69.

KuREK H., 1990, Metodologia socjolingwistycznego badania fonetyki języka mówionego środowisk wiejskich (na przykładzie kilku wsi Beskidu Niskiego), Kraków.

Kurek H., 1995, Przemiany językowe wsi regionu krośnieńskiego. Studium socjolingwistyczne, Kraków.

KuReK H., 1997, Tradycje badań dialektologicznych a przemiany językowe, [w:] H. Sędziak (red.), Tradycja badań dialektologicznych $w$ Polsce. Księga referatów z sesji językoznawczej w Olsztynie, Olsztyn, s. 129-133.

Kurek H., 2003, Przemiany leksyki gwarowej na Podkarpaciu, Kraków.

KuREK H. (red.), 2012, Języki słowiańskie w ujęciu socjolingwistycznym. Prace przygotowane na XV Międzynarodowy Kongres Slawistów, Mińsk 2013, „Biblioteka LingVariów”, t. 15, Kraków.

MALiNOWsKi L., 1880, Głoski nosowe w gwarze ludowej we wsi Kasinie oraz niektóre inne właściwości tej gwary, „Rozprawy i Sprawozdania z Posiedzeń Wydziału Filologicznego Akademii Umiejętności” t. VIII, s. 235-248.

MAŁеCKi A., 1928, Archaizm podhalański (wraz z próbą wyznaczenia granic tego dialektu). Z mapa, Kraków.

MyCAwKa M., 2012, Język polski XIV wieku. Wybrane zagadnienia, Kraków.

Nitsch K., 1910a, Próba podziału gwar polskich, „Sprawozdania z Czynności i Posiedzeń Akademii Umiejętności” XIV, nr 8, s. 3-6.

Nitsch K., 1910b, Próba ugrupowania gwar polskich (z mapa), „Rozprawy i Sprawozdania z Posiedzeń Wydziału Filologicznego Akademii Umiejętności” XLVI, s. 336-365.

Nitsch K., 1911, Mowa ludu polskiego. Z mapa, Kraków.

Nitsch K., 1913, O wzajemnym stosunku gwar ludowych i języka literackiego, „Język Polski” I, s. 33-38, 79-83, 172-179, 193-199, 281-287.

Nitsch K., 1915/1957, Dialekty języka polskiego, [w:] Encyklopedia polska Akademii Umiejętności, oprac. H. Ułaszyn i in., t. III: Język polski i jego historia z uwzględnieniem innych języków na ziemiach polskich, cz. 2, Kraków, s. 238-343; 2. wyd.: Dialekty języka polskiego z 3 mapami, Wrocław - Kraków 1957.

Nitsch K., 1948, Co to jest dialektologia historyczna?, „Biuletyn Polskiego Towarzystwa Językoznawczego" VIII, s. 119-122. 
Nitsch K., 1953, Co wiemy naprawdę o dialektach ludowych XVI wieku?, „Język Polski” XXXIII, s. 225-244.

Nitsch K., 1968, Wybór polskich tekstów gwarowych, wyd. 3, Warszawa.

Nowowiejski B., 2001, O przyszłość polskich gwar ludowych, [w:] S. Krzemień-Ojak, B. Nowowiejski (red.), Przyszłość języka, Białystok, s. 97-112.

Okoniowa J., Dunaj B. (red.), 2002, Studia Dialektologiczne II, Kraków.

Pelcowa H., 2001, Metodologia badań leksyki gwarowej u schyłku XX wieku, [w:] J. Sierociuk (red.), Gwary dziś, t. 1: Metodologia badań, Poznań, s. 183-189.

Pelcowa H., 2002, Dialektologia wobec wyzwań XXI wieku, [w:] S. Gala (red.), Dialektologia jako dziedzina językoznawstwa i przedmiot dydaktyki, Łódź, s. 383-392.

Pelcowa H., 2012, Nowe wyzwania a tradycyjne metody badań dialektologicznych, „Poradnik Językowy" nr 8, s. 5-14.

Pelcowa H., 2019, Zmiany językowe we współczesnej wsi (na wybranych przykładach z Lubelszczyzny), [w:] B. Grabka, R. Kucharzyk, A. Tyrpa (red.), Studia Dialektologiczne V, Kraków, s. 309-314.

RAK M., 2011, Materiały gwarowe z Podhala w zbiorach Archiwum Muzeum Etnograficznego im. Seweryna Udzieli w Krakowie, [w:] B. Dunaj, M. Rak (red.), Badania historycznojęzykowe. Stan, metodologia, perspektywy, „Biblioteka LingVariów”, t. 14, Kraków, s. 367-375.

RAK M., 2018, Zapożyczenia a stylistyczne zróżnicowanie gwary podhalańskiej, „Annales Universitatis Paedagogicae Cracoviensis. Studia Linguistica” 13, s. 128-138.

Rak M., Sikora K. (red.), 2014, Badania dialektologiczne. Stan, perspektywy, metodologia, „Biblioteka LingVariów”, t. 17, Kraków.

ReICHAN J., 1980, Małopolskie gwary jednonosówkowe, cz. 1-2, Wrocław - Warszawa - Kraków - Gdańsk.

Reichan J., 1999, Wspótczesny status gwar ludowych - wybrane zagadnienia, [w:] W. Pisarek (red.), Polszczyzna 20oo. Orędzie o stanie języka na przełomie tysiącleci, Kraków, S. $262-278$.

Rzetelska-Feleszko E., 2002, Spojrzenie byłego dialektologa, [w:] J. Okoniowa, B. Dunaj (red.), Studia Dialektologiczne II, Kraków, s. 105-109.

Sierociuk J., 2005, Problemy współczesnej dialektologii, „Biuletyn Polskiego Towarzystwa Językoznawczego" LXI, s. 67-76.

Sierociuk J. (red.), 2006, Gwary dziś, t. 3: Wewnętrzne zróżnicowanie języka wsi, Poznań.

SIERociuk J., 2007, Język mieszkańców wsi czy gwara? Problem nie tylko teoretyczny, „Prace Filologiczne" LII, s. 527-534.

Sierociuk J., 2016, Dynamika przeobrażeń języka mieszkańców wsi i możliwości jej badania, „Gwary Dziśs" VIII, s. 67-78.

SŁownictwo: Słownictwo i kultura ludowa gminy Wiśniowa, oprac. A. Barszczewska i in., Wiśniowa 2018.

TAmbor J., 2006, Mowa Górnoślazaków oraz ich świadomość językowa i etniczna, „Prace Naukowe Uniwersytetu Śląskiego w Katowicach”, nr 2401, Katowice.

TAмвоR J., 2015, Stylizacja - pomysł na reaktywację śląszczyzny, „Poznańskie Studia Slawistyczne" VIII, s. 215-228, [on-line:] https://doi/org/10.14746/pss.2015.8.14.

TAszycki W., 1930, Spory o pochodzenie polskiego języka literackiego, „Przegląd Humanistyczny" 3, s. 323-333.

Taszycki W., 1949, Powstanie i pochodzenie polskiego języka literackiego. Kraków kolebka literackiej polszczyzny, „Twórczość” V, z. 12, s. 100-117. 
TASzYCKi W., 1951, Geneza polskiego języka literackiego w świetle faktów historycznojęzykowych, „Lingua Posnaniensis” III, s. 145-160.

TAszycki W., 1956, Co to jest dialektologia historyczna?, „Zeszyty Naukowe Uniwersytetu Jagiellońskiego IX. Prace Językoznawcze”, nr 2, s. 59-71.

TAszYCKi W., 1961, Dialektologia historyczna i problem pochodzenia polskiego jezyka literackiego, [w:] idem, Rozprawy i studia polonistyczne, t. II, Wrocław, s. 7-148.

TAszycki W., 1973, Wstęp do Zarysu historycznej dialektologii polskiej, [w:] idem, Rozprawy i studia polonistyczne, t. V, Wrocław, s. 167-171.

URBAŃCZyK S., 1953, Zarys dialektologii polskiej, Warszawa.

Warchala J., 2003, Kategoria potoczności w języku, „Prace Naukowe Uniwersytetu Śląskiego w Katowicach", nr 2209, Katowice.

\section{What Does Historical Dialectology Actually Include? \\ (Remarks from the Perspective of a Dialectologist) \\ Summary}

The article refers to the contemporary status of Polish dialects and, at the same time, it is a voice in the debate on the scope of historical dialectology. The reference point for the works of W. Taszycki and other, later historians of language, was (and still is) the heritage of K. Nitsch, while, for dialectologists, his texts only offer a historical and/or normative value (in case of revitalization activities) as an example of language used in villages about a hundred years ago. In the publications related to historical dialectology it is assumed that the status of local dialects described by Nitsch is still valid. Dynamic changes that take place in the Polish village require revising this view and, as a result, correcting the scope of historical dialectology which, from the modern perspective, includes the works that describe dialects from the first half of the $20^{\text {th }}$ century. 